\title{
Hope and Glory: An expanded Social Strategy Diagnosis Model to incorporate Corporate Social Responsibility within Business Strategy
}

\begin{abstract}
Corporate Social Responsibility has been seen by corporations as a practice to adopt as an act of philanthropy. There have been attempts to expand the role of social responsibility to business problems however there has never been an attempt to consider the strategic alignment of social outcomes to strategy. This article analyses the role of strategy by providing a review of strategy using Whittington's generic strategies model and expanding the same model to incorporate a social strategy model that supports the anecdotal idea that social responsibility can be potentially strategic. The paper centres its argument within the Indian context.
\end{abstract}

Keywords: Business strategy, Corporate Social Responsibility, Shared Value, Bottom of the Pyramid.

\section{Introduction}

India, Asia's third largest economy, has registered an economic growth of $7.4 \%$ for 2014 and the World Bank predicts that by the year 2025 India will contribute $6 \%$ to $11 \%$ of the world's GDP. However, the World Development Indicators point out that $21.9 \%$ of the population of India still lives below the national poverty line.

Academically, the Corporate Social Responsibility debate is long-standing. Authors have not reached a consensus to what is exactly Corporate Social Responsibility and what value it adds to companies. There are divergent positions academically on different approaches to strategy formulation and the view of shareholder value versus stakeholder responsibility has been discussed extensively.

The Indian Government has tried to make mandatory for companies to spend $2 \%$ of their profits in Corporate Social Responsibility activities. However, lack of clarification on the role that Corporate Social Responsibility has in the strategic activities of any company will not yield any visible outcome when it comes to translating a feasible business strategy to business practices.

Arora and Puranik (2004) point out that CSR in India is still 'in a confusing state' where companies stand divided between philanthropic obligations and sustainable 
business strategy. A recent example is the case for Wal-Mart in India. Early in 2012, in an unprecedented move, the Indian Government allowed for the first time foreign retailers to open stores in the country. Companies like Wal-Mart, IKEA or Starbucks saw a door of opportunity opening up to expand their business operations to the South Asia market. However, in November 2012, the first report of cases of bribery in WalMart's operations in Mexico, Brazil, China and India came to light exposing violation of foreign investment rules that led to the immediate suspension of all the employees of Wal-Mart in India, including the Chief Financial Officer (The New York Times, 2012).

This paper tries to address the complexity of the conceptualization of strategy and of Corporate Social Responsibility and attempt to explain if Corporate Social Responsibility can be a strategic tool for companies in India to obtain competitive advantage. For the purpose of this paper, the key topics to discuss will focus on the prescriptive and emergent view of business strategy and the profit maximisation versus processual debate, with a focus on alternative models of social responsibility: in particular, the Bottom of the Pyramid and Creation of Shared Value. The outcome of this paper is to address the literature gap regarding the alignment of Corporate Social Responsibility practices with business strategies and produce a diagnostic model, using Whittington's generic perspectives on strategy, to support the anecdotal idea that Corporate Social Responsibility can be aligned with business practices.

\section{Methodology}

The methodology applied is a critical review of the relevant literature in corporate social responsibility and business strategy. The literature search focused on the use of secondary literature. The first step was to define the search parameters and a thorough review on literature that was relevant on the subject. The publications found were too broad. To help to define the subject matter and refine the search, keywords were generated. Those keywords were applied to construct a relevance tree that posed the question 'Can Corporate Social Responsibility be incorporated in business strategy?' This relevance tree led to the research of two main concepts - Corporate Social Responsibility and Business Strategy - and those two concepts were further on refined to other associated research terms like stakeholder theory, corporate governance, business ethics, microfinance and strategic corporate social responsibility. Those research terms were further deconstructed in other relevant search terms. To ensure that 
the searches were objective and consistent the terms were catalogued relatively to their eligibility on the research question based on a pre-determined set of criteria. The criteria applied to the research included the date of publication, theory relevance and reference in other publications, position of support or contradiction to the central theme of research, bias and methodological omissions. The second search with the applied criteria was refined in the secondary literature that addressed directly the topic in question.

The limitation to this paper is the lack of primary data collected to determine the hypothesis posed. The validity of this paper is limited to a pure theoretical approach that needs to be further investigated with primary data collection.

\section{A strategic review}

There has been a longstanding academic debate on the different definitions of strategy. The concept is subject to different interpretations and definitions according to the perception of reality of the strategist (Morgan, 1998). There are many theoretical perspectives to the concept of strategy. Mintzberg (1998) created ten schools of strategy that can be classified in three groupings: the prescriptive nature of strategy (the design, the planning and the positioning schools); the descriptive nature of strategy (the entrepreneurial, the cognitive, the learning, the power, the cultural, and the environmental schools); and, the emergent nature of strategy (the configuration school). The purpose of this section is to provide an overview of the debate to inform the reader and analyse Whittington's Generic Perspectives on Strategy model (2001) to the topic in discussion, correlating when possible with Minztberg's schools.

\section{Prescriptive versus Emergent Strategy}

The prescriptive nature of strategy assumes that strategy formulation is a controlled, intentional and a prescriptive process (Argenti, 1974, Steiner, 1969, Ansoff, 1965). According to Whittington's model (2001), both the Classical and the Systemic approach to strategy is prescriptive in nature. The Classical approach has its roots in the work of authorities such has Chandler (1962), Ansoff (1965) and Porter (1979). In the context of Mintzberg's (1998) schools of thought it is synonymous of the Design, Planning, and Positioning school of strategy. The Design school of strategy is based on long-term planning processes and assumes that strategy is a response to a constant and stable 
environment. Ansoff (1965) considered that strategy in corporations should be developed according to the environmental challenges presented and the S.W.O.T model incorporates the vision of a controlled and conscious process of formal planning. This school of thought is the most influential where strategy is configured through a fit between internal capabilities and external possibilities (Mintzberg, 1998). The Planning school of strategy takes a formal approach to the creation of strategy with the creation of a series of steps from the situation analysis to the execution and control of the strategic process (Ackoff, 1983). This school of strategy led to the popular scenario planning, a tool created in the predicament that strategies should be able to speculate potential future outcomes. As described by Wack (1985) scenario planning is an exercise that is 'less (reliant) on figures and more on insight'. The Positioning School of strategy accepted the two previous schools of thought and extended them. This particular school of thought addresses the dominance of the competitive environment. The dominant strategic approach to the competitive environment theory is Porter's Five Forces Model in which the author created a framework to assess the degree of intensity of each force and the degree of attractiveness in the industry in order to achieve competitive advantage (Porter, 1979). Porter (1980) argues that 'competitive strategy is about developing a defendable position in an industry.'

The main difference between these three schools of thought in the deliberate process of strategy is that while the design and planning school don't consider any limitations on strategies, the positioning school argues that a company must choose a unique strategy (Mintzberg et al, 1998). The prescriptive stream gives a blueprint of strategy formulation by assuming that the environment where a company operates is stable and strategy formulation is responding to that environment. The analysis of the external and the internal environment is of a long-term monitoring.

The Systemic approach to strategy shares the same long-term perspective of strategic planning as the Classical approach. Granovetter (1985) argues that social relations influence economic structures. However, this approach also emphasises a respect for the use of social resources over profit maximization, which will be further explored in the following section. The systemic approach takes a sociologic, anthropologic, political science and historic perspective to the development of strategy (Granovetter, 1985). This perspective aligns with the Entrepreneurial school, the Cognitive school and the Cultural School. The Entrepreneurial school of strategy addresses the soft elements 
of leadership as the basis for strategy formation unlike the classical approach that recognises the figure of the architect however emphasises the conceptualisation of strategy over leadership (Mintzberg, 1998). This school of strategy emphasises vision or direction as the key element to the construction of strategy. The approach is broadly deliberate however one can argue that the vision is more of 'an image rather than an articulated plan' (Mintzberg, 1998). The Cognitive school of strategy, takes the perception of strategy as a image and explored further strategy formation using cognitive psychology: these authors see strategy as an interpretation of the world (Mintzberg, 1998). One of the most prominent authors Simon (1957) saw strategy as a complex and large event that derives from the capability of the decision-maker to process information. Makridakis (1990) recognised that judgemental bias have consequences to the decision-making process. The Cultural school of strategy roots its ideology in the notion that culture maintains strategic stability (Mintzberg, 1998). In this perspective, organisational culture is a definitive factor to strategy creation as the 'expressive social tissue' (Pettigrew, 1985). This school of thought can be considered the one most closely associated with the systemic perspective, as it perceives strategy formation as a process of social interaction based on shared beliefs and values (Mintzberg, 1998).

Both the classical and systemic approach to strategy interrelates and configures the long-term planning of a company that makes the configuration of the internal and the external environment as the key to achieve competitiveness. However this process does not exist without criticism. The concept of emergent strategies as proposed by Whittington (2001) through the generic strategies model based on the work developed by authors such has Henderson (1989) and Mintzberg $(1998,1985)$ is the fiercest critic to the classical approach, which will be discussed in the next section.

Whittington's classical and systemic approach can be applicable to the Indian context. A recent report by McKinsey Global Institute (2014) revealed that productivity growth and private consumption were the main drivers for the recent poverty reduction in the country, however the same report states that the empowerment gap could be greatly reduced if India creates more non-farm jobs and increases public spending on basic services. The potential growth is barred due to the prevalence of an unorganised sector and sub-scale enterprises (McKinsey Global Institute, 2014). The authors are of the opinion that the classical and systemic approach to strategy would be a beneficial tool to 
governmental and small enterprises alike. The lack of long-term strategic view can be a potential contributor to the inertia to reduce the empowerment gap. McKinsey's (2014) report argues that each state of India, with central government support, should develop a long-term strategy considering the internal and external constraints of each state. This will be further investigated with the debate between profit maximisation and pluralist outcome of strategy.

The configuration of the Emergent Strategy builds on the critiques to the formalized strategic planning process and acknowledges that the environment can be disruptive. This school of thought asserts that companies should be constantly monitoring the internal and external environment and organisations should be prepared for constant change (Christensen and Overdorf, 2000, Miller and Morris, 1999, Brown and Eisenhardt, 1998, Tushman and Anderson, 1997, D’Aveni, 1994). Mintzberg (1987) constructed the idea of emergent strategies by criticizing the deliberate process. The premise of his reasoning is that: the future is impossible to be predicted; long-term goals are not always foreseen; culture and leadership in an organisation are important when it comes to strategic decisions; deciding on what strategy to pursue and implementing it are interrelated processes. This stream of thought gives relevance to the organisational and social aspects of strategic formation and not to the construction of detailed plans.

According to Whittington's model (2001) the Evolutionary and Processual schools of thought are emergent in nature. These two schools of thought assume that no company can no longer forecast into the future or cope with the complexities of a world that perpetually changes by relying on one deliberate strategy (Grant, 2010). The Evolutionary approach argues that strategy emerges from natural competition - only the stronger will survive (Henderson, 1989, Alchian, 1950). The Environmental school perceives strategy as a mirroring process by positioning the external environment as the central element in strategy formation (Mintzberg, 1998). The premise is that the organisation is a passive element that needs to respond to the external forces as the contingent approach to strategy, in this form, strategy emerges as a reaction to the external environment (Miller, 1979). The Configuration school of strategy debates that strategy it doesn't entail change but rather continuity. Minztberg (1998) argues that strategy can be described as a stable configuration, however the same configuration will only be permanent for a certain period of time. The same author argues that there will be some process of transformation that inevitably will disrupt the stability. The key for a 
successful strategic management is to sustain stability but also recognise the need for creative destruction as a transformation process. Therefore, strategy can be considered a plan, pattern, position, perspective and a ploy (Mintzberg, 1998).

The Processual approach sees strategy as a messy and complex phenomenon (Whittington, 2001). This approach resonates with the Learning and Power schools of strategy (Mintzberg, 1998). The Learning school of strategy assumes that organisations are complex and that patterns of collective behaviour emerge over time, which in turn will lead to a management by change (Mintzberg, 1998). Quinn (1980) argues that strategy is an incremental process rather than an isolated event. Nelson and Winter (1982) build on Quinn's premise and state that strategy is an evolutionary process. Mintzberg (1987) designs an image of 'crafting strategy' remarking that strategy can occur in three ways: the intended strategy or the plan laid by the firm; the realized strategy, the strategy which is in fact pursued by the company and the unrealized strategy the plan left behind due to changing circumstances in the environment; the emergent strategy, derives from experience and learning from all the other strategies and meets the external environment's needs and demands. The Power school of strategy also resonates with the Processual perspective. According to Mintzberg (1998) power surrounds the organisation. The author makes the distinction between micro (internal) and macro (external) power and argues that politics greatly influence the decision-making process through a position of bargaining and negotiation with different stakeholders (Bolman and Deal, 1997). Hence, the same authors argue that strategy can't be a deliberate process when perception and interests in the organisation are prominent in an organisation.

A recent argument against Mintzberg theory is the research of Miller and Ireland (2005) on the role of intuition in strategic decision-making. For these authors' examples of what Mintzberg would call emergent strategies such as the Honda entry in U.S bike market, the Southwest Airlines or the Walkman, Miller and Ireland refer to as examples of intuition. The authors recognize the importance of 'exploration' in the rapid and changing environment of the $21^{\text {st }}$ century but the argument is that exploring new strategies should be controlled. The so called 'hunch' is only important when planning for ambiguous futures and the authors' remark that they are often flawed giving the example of FedEx Zap Mail or America Online's Pittman. 
The notion of an emergent process to strategy formation is not new in the Indian context. Rajdou, Prabhu and Ahuja (2012) address the concept of Jugaad Innovation. This concept can be defined as a flexible approach to the creation of products and services in the Indian sub-continent. One of the examples of a company that pursued successfully a strategy in a disruptive environment is the Tata Group. Tata Motors, in 2009 , launched the $£ 1190$ (one lakh of rupees) Nano which is the epitome of the cheapest car in the world. The manufacture of this particular vehicle involved nonlinear thinking and improvisation on their business strategy (Rajdou, Prabhu, Ahuja, 2012). McGrath (2013) coined the term transient advantage to express the idea of rapid strategic formation. The core focus for this author is that in order for organisations to survive in an environment with rapid transformation strategy needs to emerge as a more fluid process - emergent.

In conclusion, there is a primal distinction between the two processes analyses. While the deliberate process focuses on control and realized intent the emergent process emphasizes the concept of learning and change. These two strategic processes form the first part of Whittington's generic model (2001) and is the strategic foundation for the social strategy diagnosis model (Figure 1).

\section{Figure 1: Whittington's generic strategy model (2001)}

\section{Corporate Social Responsibility: Strategic Reality or Utopia?}

Throughout time, from Aristotle's to Adam Smith, the role of business in society has always been debated. On one side, are those that see the individual's morality shaped by the society he/she is inserted in and therefore in order for the individual to be a moral being he/she must be part of a moral society; on the other side, are those that regard self-interest as the prevalent drive in society's welfare, disregarding kindness or altruism. This debate over the decades transpired to business, specifically on what should be the role of business in society. Whittington's generic strategy model (2001) formulates two outcomes to a business strategy: profit maximisation or a pluralistic outcome. These two will be the main focus for the debate on this section in arguing why this model is flawed and how it can be extended to incorporate modern realities concerning social responsibility of businesses. 
Friedman (1970) argued that 'The Social Responsibility of Business is to Increase its Profits'. This view of business builds on the premise that the only interest to be respected is the creation of shareholder value. Hayek (cited in Harrigan, 2010) builds on the idea of creation of shareholder value and argues that social considerations in business produce 'undesirable results'. Friedman (1970) refuses to acknowledge social responsibility of business stating that that it is a characteristic bound to individuals and not companies. The author takes the position once assumed by Adam Smith (1776) and argues that business is created to '(...) use its resources and engage in activities designed to increase its profits.' (Friedman, 1970) The Classical and Evolutionary schools of strategy pursue profit maximisation (Whittington, 2001). While the Classical approach is the epitome of Adam Smith's economic views of self-interest of the CEO and top management in securing profit maximisation, the evolutionary approach perceives that markets will secure profits through natural competition (Henderson, 1989). This perspective of maximisation of profit has been criticised. Some authors disagree on the perspective that shareholder and stakeholder value are not bound together in zero-sum terms (Harrigan, 2010). Prahalad (2010) argues that serving the poverty line is actually a new market opportunity and Cadbury (2002) objects to Friedman's unitary point of view. These criticisms build on the conceptualization of a pluralistic society herein lay in Whittington's Processual and Systemic schools of strategy.

McGuire (1963) states that 'A pluralistic society is one in which there is wide decentralization and diversity of power concentration.' Power is distributed among society. Handy (2002) builds in the assertion of the pluralistic view by stating that businesses have a broader role in society. For this author profits as a mere end is insufficient. Whittington's Processual and Systemic schools of strategy address the pluralistic aspect of strategy. The Processual approach will pursue the optimal solution that will 'satisfy' the interested parties (Whittington, 2001), while the Systemic school of strategy factors in social relations with the process of strategy formation (Granovetter, 1985). The advantage of pluralism is the view of society as a whole with a variance of stakeholders interfacing in society. The fiercest critic to the same notion of pluralism is that whatever sustains the profitability of the company will be the primary focus and therefore the positive repercussions it has in society will be a simple consequence of business actions (Friedman, 2005). (Figure 2) 
In an Indian context, one can argue that there is an active struggle between profit maximisation and a pluralistic approach. Malhotra (2014) argues that there are fundamental five key areas that need strategic development in the country from both the private, non-for-profit and government sector: infrastructure, inefficiency, inequality, innovation and independence (the five i's). The same author argues that lack of strategic initiative to support infrastructure development; innovation creation and elimination of poverty and inequality prevent the country to be an economic powerhouse. This is the same argument this paper makes. There is a comprehensive lack of strategic formulation that addresses the perspective of a pluralistic outcome as envisioned by Whittington's model (2001). The next section will analyse the possible alternatives to this problematic by extending the Generic Strategy Model as designed by Whittington (2001).

\section{Figure 2: Whittington's generic strategy model (2001)}

When addressing the outcomes of strategy, in particular the pluralistic approach of strategy the concept of Corporate Social Responsibility arises in discussion. Corporate Social Responsibility (CSR) can be defined as the continuing commitment by business to behave ethically and contribute to economic development while improving the quality of life of the workforce and their families as well as of the local community and society at large.' (WBCSD, 2000). Carroll (1979, in Bucholtz and Carroll, 2009) presented CSR as a responsibility of business to encompass the economic, legal, ethical and discretionary expectations that society imposes. Carroll's conceptualization of the CSR pyramid portrays four components. The basic building block is the financial sustainability of the company. Businesses also must comply with the law of the country they operate in. The ethical responsibility of business translates into acting in what the society considers to be right, just and fair. Finally, the discretionary component is the expectation upon the business to act as good corporate citizens (Bucholtz and Carroll, 2009). For Carroll (1991) the discretionary responsibility is based on the desire of businesses to engage in social actions such as corporate giving, employee volunteering, partnerships with local governments and other entities and involvement with the community.

The question this paper debates is whether Corporate Social Responsibility can potentially play an active part in delivering either a prescriptive or an emergent strategy. This paper also debates if there are other social responsibility models that can be applied in a strategic context using Whittington's generic strategies model as a basis. 
Bernstein (2010) argues that Corporate Social Responsibility became synonyms of aid where industrialised countries and large multinationals give large sums of money through their taxes to help causes in sub-developed countries. The same author remarks that companies at large have been targeted for social malpractices whether are sweatshops, child labour or fair trade but organizations that are the proponents of the concept of social responsibility have also largely failed in overseeing that their principles are applied throughout the organization. One can argue that companies drift from pursuing acts of pure philanthropy to environmental sustainability to the pursuit of creation of shared value, which will be shortly discussed (Rangan, Chase and Karim, 2015). In sum, there is a lack of strategic alignment. Our reasoning behind the lack of strategic alignment with Corporate Social responsibility activities places CSR in the social strategy diagnosis model in the centre with a 'stuck in the middle' approach (Figure 3).

An alternative to the concept of Corporate Social Responsibility is the Bottom of the Pyramid. Prahalad (2010) states that '(...) poverty alleviation can become a business development task (...)'. For the author there are fundamentally three markets in which business can cater their products for: the mature economy, the aspiring middle class and, the Bottom of the Pyramid. The general assumption multinationals make is that there is no purchasing power in the Bottom of the Pyramid. For the proponents of the concept of Bottom of the Pyramid is that the assumption is flawed. The reasoning is that the Bottom of the Pyramid is a consumer market that leads businesses to innovate their business models in order to develop new products and services. A recent research by Simanis and Duke (2014) argues that the concept of the Bottom of the Pyramid is not been successful. The argument these authors make is that profitability at the bottom of the pyramid is achievable but needs strategic alignment. The reason behind the lack of strategic alignment with the products and services sold at the Bottom of the Pyramid is primarily to due with the fact companies don't understand two fundamental problems: consumer behaviour of people at the Bottom of the Pyramid and product creation and delivery to the final consumer (Simanis and Duke, 2014). We are of the same opinion when it comes to lack of strategic integration to social responsible activities. This concept is supported by the likes of Bernstein (2010). This author develops a critic approach to the western countries ideas of sustainable development by stating that it is 
ridiculous to pursue economic growth in developing countries by advocating '(...) global standards of labour, environment and so on (...)'. Business should focus in achieving profitability and pressures for global standards should be on government's shoulders and legislature. Danone, the French multinational supplier of dairy products and bottled water, has set up a BOP division where it develops business models aimed at making healthy food affordable and accessible to low-income people in developing nations. The company recently developed Fundooz which is a $£ 0,05$ milk dessert sold only in Northern India. Danone has posted sales targets of nearly 7\% in 2010 and it's considered one of the best performers in the food industry (Radjou, Prabhu, Ahuja, 2012). Based on the above we considered that the Bottom of the Pyramid adopts a pluralistic outcome to strategy pursuit through the creation of products and services that cater low-income societies. (Figure 3)

An opposite view to the concept of the Bottom of the Pyramid is that of Porter and Kramer (2002) that remark that philanthropy has been used as public relations to enhance the company's brand image. The argument that is brought to light is that companies to improve competitiveness can use philanthropy as a competitive advantage weapon. Porter and Kramer by combining the external and internal perspectives of the industry argue that companies should also include in their strategic position the 'combined social and economic benefit'. The authors created the concept of Creation of Shared Value (CSV). The authors argue that CSV is not charity or social responsibility: it is a new way to achieve economic success. Shared value is defined as '(...) policies and operating practices that enhance the competitiveness of a company while simultaneously advancing the economic and social conditions in the communities in which it operates.' (Porter and Kramer, 2011) For the authors CSV is re-inventing products and markets: redefining productivity in the value chain; or, building supportive industry clusters. Especially relevant is the fact that these two authors explicitly state that CSV supersedes CSR. The authors take a critique position regarding CSR stating it's all about philanthropy due to external pressures and that it focuses on the company's reputation while, CSV's purpose is to bring economic and societal benefits relative to cost; it is the base of profit maximization. Take PepsiCo's example of reduction of water consumption throughout the supply chain. The company needed drastically to use efficiently the water consumed in their factories in order to improve product outputs and reduce costs. They developed an eco-friendly agronomic technique called 'direct 
seeding' of rice paddies. Direct seeding avoids puddling, transplanting and growing in standing water (three operations that are water-intensive when planting rice). With this technique the company is saving on average $30 \%$ of the usual requirement of water in paddy cultivation. Indirectly, the company is also contributing with this technique for a $70 \%$ cut of greenhouse emissions. Therefore, the CSV model is closely positioned in the profit maximisation outcome of strategy (Porter and Kramer, 2011) (Figure 3).

\section{Figure 3: Social Strategy Diagnosis Model}

\section{The Social Strategy Diagnosis Model}

Corporate Social Responsibility has been the synonymous of 'doing good', 'citizenship, philanthropy, sustainability', and 'discretionary', 'separate from profit maximization' (Porter and Kramer, 2011). The stellar example of CSR is the British cosmetic retailer and manufacturer, The Body Shop, with the epitome of doing business responsible and pioneering fair trade practices across the globe. Without any demerit to its principles the company's view of doing the right way of business has led to a steady decline of its sales figures throughout the year and consequently its profits. The company's CSR vision lacks on strategic integration and that is the reason why the CSR vector is in the middle of the model. The CSR ideology lacks on a business strategy that can translate into feasible business practices. This paper argues that beyond pure philanthropy CSR lacks improvements across the value chain in order to deliver value; lacks innovation in business models that are specifically designed to address the challenges of emergent economies; social programmes should be aligned with the company's purpose and values and deliver value that creates both social and stakeholder value; top management should be actively involved in the creation of a CSR strategy that delivers an intended outcome.

The Bottom of the Pyramid model is closely associated with a pluralistic view. Take for instance Aravind Eye Care in India. There are 9 million people in India that suffer from some degree of eyesight illness. Dr. Padmashree Venkataswamy had a vision to eradicate blindness in the state of Tamil Nadu, in India, by providing free eye care services to the poor, specifically cataract surgeries. He set up several eye camps in order to reach to rural communities. Each eye camp will have a sponsor that cover the expenses for the medical care and other expenses related to the organization of the camp. This system is financially self-supporting and never depended on any grants or 
donations from the Government of India (Prahalad, 2010). This example can be considered of a planned, intentional strategy of delivering eye care throughout the state of Tamil Nadu but the intention is to be self-sustainable and to cater to those at the poverty line and therefore it is positioned as a pluralistic outcome of strategy.

The reason behind CSV positioning as a profit maximisation outcome of strategy is dependent upon the fact that its value is to bring economic and social benefits relatively to cost. The idea is to create profit maximization while creating in consequence community value creation. It's not against capitalism; instead it considers what is the next step of the ideology of capitalism. Nespresso is one of the leading coffee brands, recognized by the adverts with George Clooney, the American actor. Nespresso is part of Nestle, one of the largest multinationals in the world. Nestle has used the idea of CSV effectively in its business practices. The clusters of companies, suppliers, service providers, and IT infrastructure and so on in the same geographical area influence productivity and innovation. Coffee regions are also clusters for productivity and innovation if you are in the coffee making industry. Nestle sought out to look for new procurement practices, such has agricultural, technical, financial, and logistical in each coffee region to improve the quality of local production. In the process the company had to secure essential agricultural inputs such has plant stock, fertilizers and irrigation equipment; strengthen regional farmers' cooperation and finance wet-milling facilities. This led to an intensive collaboration with Rainforest Alliance, a worldwide NGO, which taught the farmers sustainable practices in coffee production. This in turn benefit Nestle in terms of improving operations productivity and quality of coffee produced (Porter and Kramer, 2011).

The Social Strategy Diagnosis model is a diagnostic tool that used Whittington (2001) Generic Strategic model as the starting point on how to convert social enterprises practices in feasible strategic directions. According to the framework there are 9 possible strategic positioning: The classical proposition formulated by Whittington's (2001) classical (position 1), evolutionary (position 2), systemic (position 3) and, processual (position 4). The Neo-Classical positioning of the company for prescriptive CSV strategic positioning (position 5) and the Progressive positioning in regards the creation of shared value as an emergent process (position 6). The Method positioning strategically addresses the needs of the BOP market by following a planned strategy 
(position 7), while the Development positioning creates emergent strategies that cater to the BOP market (position 8) and the equidistant positioning is located in the intersection between the quadrants and represents the CSR vector (position 9/Figure 4). The argument this paper makes is that by using this tool companies should be able to assess their strategic position in regards to the development of new products and services in emergent markets, specifically in India. At present, there are only models of social enterprise and sustainability that have been developed and that focus on either the market to be served or the operational effectiveness of companies. We argue that these models can be included and designed with a strategic purpose.

This paper also argues that Corporate Social Responsibility has a strategic potential that is unfulfilled and therefore at present is 'stuck in the middle'. The authors don't disregard the eventual possibility for the modification of the present model that addresses a strategic shift in case Corporate Social Responsibility becomes truly strategic.

\section{Figure 4: Social Strategy Diagnosis Model}

\section{Conclusion}

From the above review it can be highlighted that Corporate Social Responsibility has a strategic potential that is unfulfilled. The paper started by presenting a review of Whittington's generic strategy model with an Indian perspective to strategy formation. Finally, the research paper addressed the topic of Corporate Social Responsibility and the lack of strategic focus. The premise used is that an expanded strategy model should be considered when addressing Corporate Social Responsibility and that the concepts of Bottom of the Pyramid and Creation of Shared Value should be considered as alternative models of strategic intent towards social responsibility. 


\section{References}

Ackoff, R. L., 1983, Beyond Prediction and Preparation, Journal of Management Studies, January, pp. 59-69.

Ansoff, H.I., 1965, Corporate Strategy, $1^{\text {st }}$ Edition, and New York: McGraw Hill.

Argenti, J., 1974, Systematic Corporate Planning, London: Nelson.

Arora, B., Puranik, R., 2004, A Review of Corporate Social Responsibility in India, Palgrave Macmillan, 47 (3), pp. 93 -100.

Bajaj, V., 2012, India Unit of Wal-Mart suspends employees, The New York Times, Available from: http://www.nytimes.com/2012/11/24/business/global/wal-marts-indiaventure-suspends-executives-as-part-of-bribery-inquiry.html? $\mathrm{r}=1 \&$

Bernstein, A., 2010, The case for business in developing economies, $1^{\text {st }}$ Edition, Johannesburg: Penguin Books.

Brown, S. L., and Eisenhardt, K.M., 1998, Competing on the Edge: Strategy as structured chaos, $4^{\text {th }}$ Edition, Boston: Harvard Business School Press.

Bucholtz, A.K., and Carroll, A. B., 2009, Business and Society: Ethics and Stakeholder Management, $8^{\text {th }}$ Edition, Canada: Cengage Learning.

Chahoud, T., 2007, Corporate Social and Environmental Responsibility in India Assessing the UN Global Compact's Role, Bonn: German Development Institute.

Christensen, C.M., and Overdorf, M., 2000, Meeting the Challenge of Disruptive Change, Harvard Business Review, March-April 2000, pp. 66 - 78.

Collins, D., and Montgomery, C. A., 1995, Competing on resources: strategy in the 1990 's, Harvard Business Review, July - August, pp. 118 -128.

D'Aveni, R. A., 1994, Hypercompetition: Managing the dynamics of strategic manoeuvring, $1^{\text {st }}$ Edition, New York: The Free Press.

Davis, K., Blomstrom, R. L., 1975, Business and Society: Environment and Responsibility, $3^{\text {rd }}$ Edition, New York: McGraw Hill.

Friedman, M., 1970, The Social Responsibility of Business is to increase its profits, New York Times Magazine.

Granovetter, M., 1985, Economic Action and Social Structure, American Journal of Sociology, Volume 91, Issue 3, pp. 481-510.

Grant, R. M., 2010, Contemporary Strategy Analysis, UK: Wiley Publishers.

Handy, C., 2002, What's a business for? Harvard Business Review, December 2002, pp. $49-55$. 
Harrigan, B., 2010, Corporate Social Responsibility in the $21^{\text {st }}$ Century: Debate, Models and Practices across Government, Law and Business, $1^{\text {st }}$ Edition, Cheltenham: MPG Books Group.

Henderson, B.D., 1989, The Origin of Strategy, Harvard Business Review, NovemberDecember, pp. 139 - 143.

Johnson, G., Scholes, K., and Whittington, R., 1998, Exploring Corporate Strategy, $8^{\text {th }}$ Edition, Essex: Pearson Education Limited.

Karim, S., 2015, The Truth about CSR, Harvard Business Review, January -February, pp. $4-9$.

Kay, J., 1993, Foundations of Corporate Success, $4^{\text {th }}$ Edition, New York: Oxford University Press.

Malhotra, V., 2014, India has to Evolve, Knowledge at Wharton, Available on: http://knowledge.wharton.upenn.edu/article/mckinseys-vikram-malhotra-indiaevolve/.

McGrath, R. G., 2013, Transient Advantage, Harvard Business Review, June, pp. 4 10.

McGuire, J.W., 1963, Business and Society, $1^{\text {st }}$ Edition, New York: McGraw Hill.

McKinsey Global Institute, 2014, From poverty to empowerment: India's imperative for jobs, growth, and effective basic services, Available on: www.mckinsey.com/mgi

Miller, C.C., and Ireland, R.D., 2005, Intuition in strategic decision making: friend or foe in the fast-paced $21^{\text {st }}$ century? Academy of Management Executive, Vol. 19, No. 1, pp. $19-30$.

Miller, W. L., and Morris, L., 1999, $4^{\text {th }}$ Generation $R \& D, 2^{\text {nd }}$ Edition, New York: John Wiley \& Sons.

Mintzberg, H., Ahlstrand, B., and Lampel, J., 1998, Strategy Safari, New York: The Free Press.

Mintzberg, H., 1987, Crafting Strategy, Harvard Business Review, July 1987, pp. 66 75 .

Mintzberg, H. and Waters, J. A., 1985, Of Strategies, Deliberate and Emergent, Strategic Management Journal, Vol. 6 pp. 257-272.

Morgan, G., 1998, Images of Organization, $3^{\text {rd }}$ Edition, California: Sage Publications Inc.

Porter, M. E., and Kramer, M. R., 2011, Creating Shared Value, Harvard Business Review, January - February 2011, pp. 4 - 17. 
Porter, M.E., and Kramer, M. R., 2002, The Competitive Advantage of Corporate Philanthropy, Harvard Business Review, December 2002, pp. 5 - 16.

Porter, 1980, Competitive Strategy, $3^{\text {rd }}$ Edition, New York: Free Press.

Porter, M.E., 1979, How competitive forces shape strategy, Harvard Business Review (March/April).

Prahalad, C.K., 2009, The Fortune at the Bottom of the Pyramid: Eradicating Poverty through Profits, $5^{\text {th }}$ Edition, New Jersey: Wharton School Publishing.

Prahalad, C.K., and Hamel, G., 1990, The core competence of the organization, Harvard Business Review, 68 (3), pp. 79 - 91.

Radjou, N., Prabhu, J., Ahuja, S., 2012, Jugaad Innovation: A frugal and flexible approach to innovation for the $21^{\text {st }}$ century, London: Random House Group Limited.

Saunders, M., Lewis, P., Thornhill, A., 1997, Research Methods for Business Students, London: Financial Times, Pitman Publishing.

Simanis, E., and Duke, D., 2014, Profits at the Bottom of the Pyramid, Harvard Business Review, October, pp. 4 - 9.

Stalk G. Jnr, Evans, P., and Schulman, L.E., 1992, Competing on capabilities: the new rules of corporate strategy, Harvard Business Review, March -April, pp. 57 -70.

Steiner, G.A., 1969, Top Management Planning, London: MacMillan.

The World Bank, 2013, World Development Indicators, Available from: http://data.worldbank.org/country/india\#cp_wdi

Tuschman, M. L., and Anderson, P., 1997, Managing Strategic Innovation and Change, $1^{\text {st }}$ Edition, New York: Oxford University Press.

Wack, P., 1985, Scenarios: Uncharted Waters Ahead, Harvard Business Review, September-October, pp. 73-89.

Whittington, R., 2001, What is strategy - and does it matter?, $2^{\text {nd }}$ Edition, London: Thomson Learning.

World Business Council for Sustainable Development, 2000, Corporate Social Responsibility: making good business sense, London: Red Letter Design. 


\section{Figures}

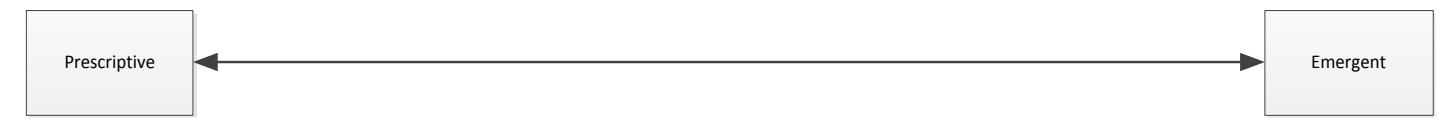

Figure 1: Whittington's generic strategy model (2001)

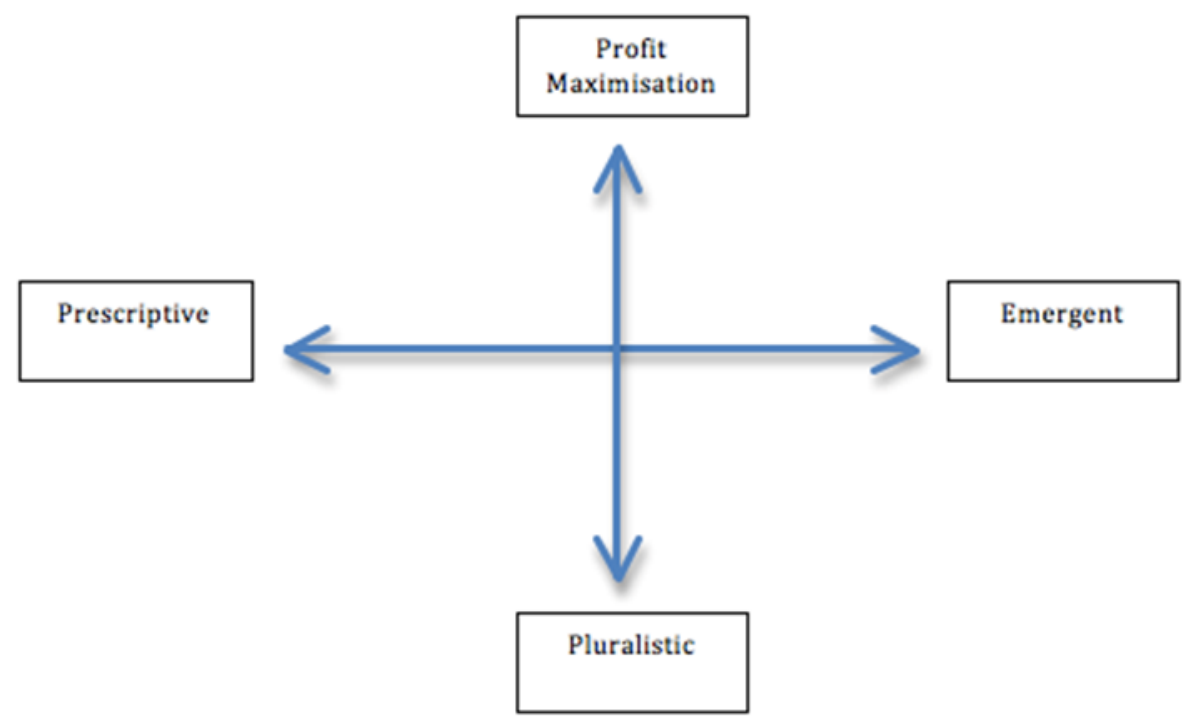

Figure 2: Whittington's generic strategy model (2001) 


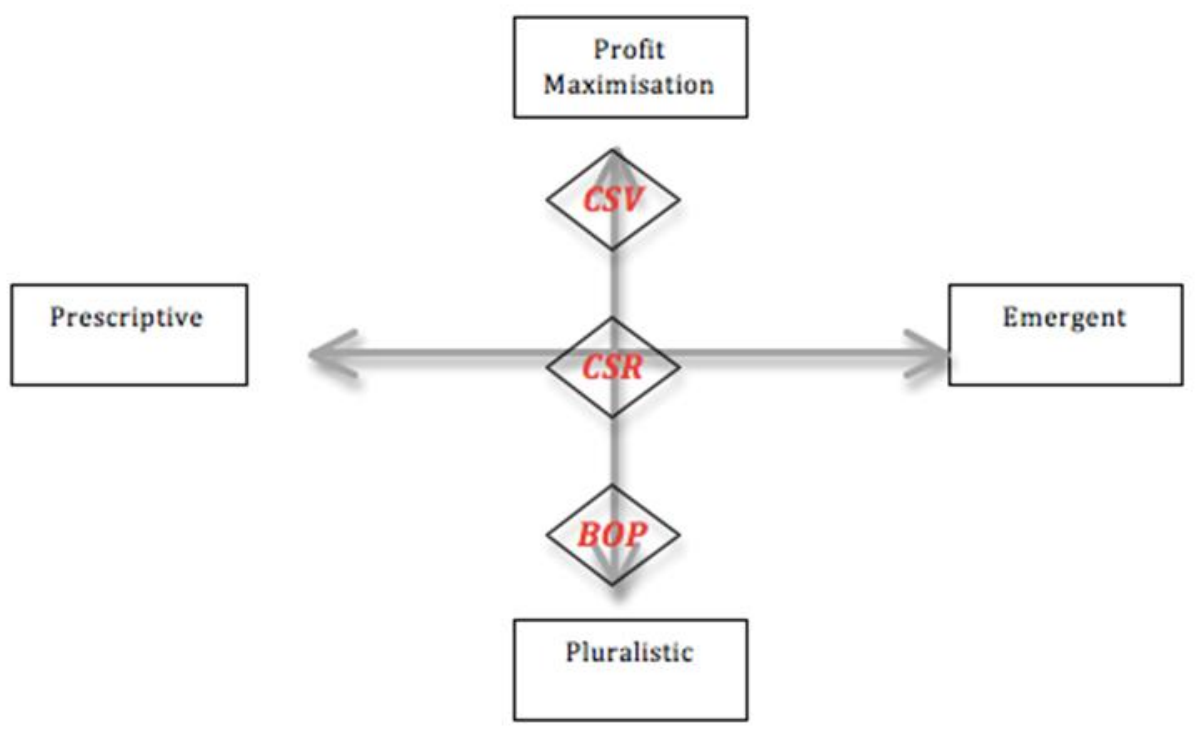

Figure 3: Social Strategy Diagnosis Model

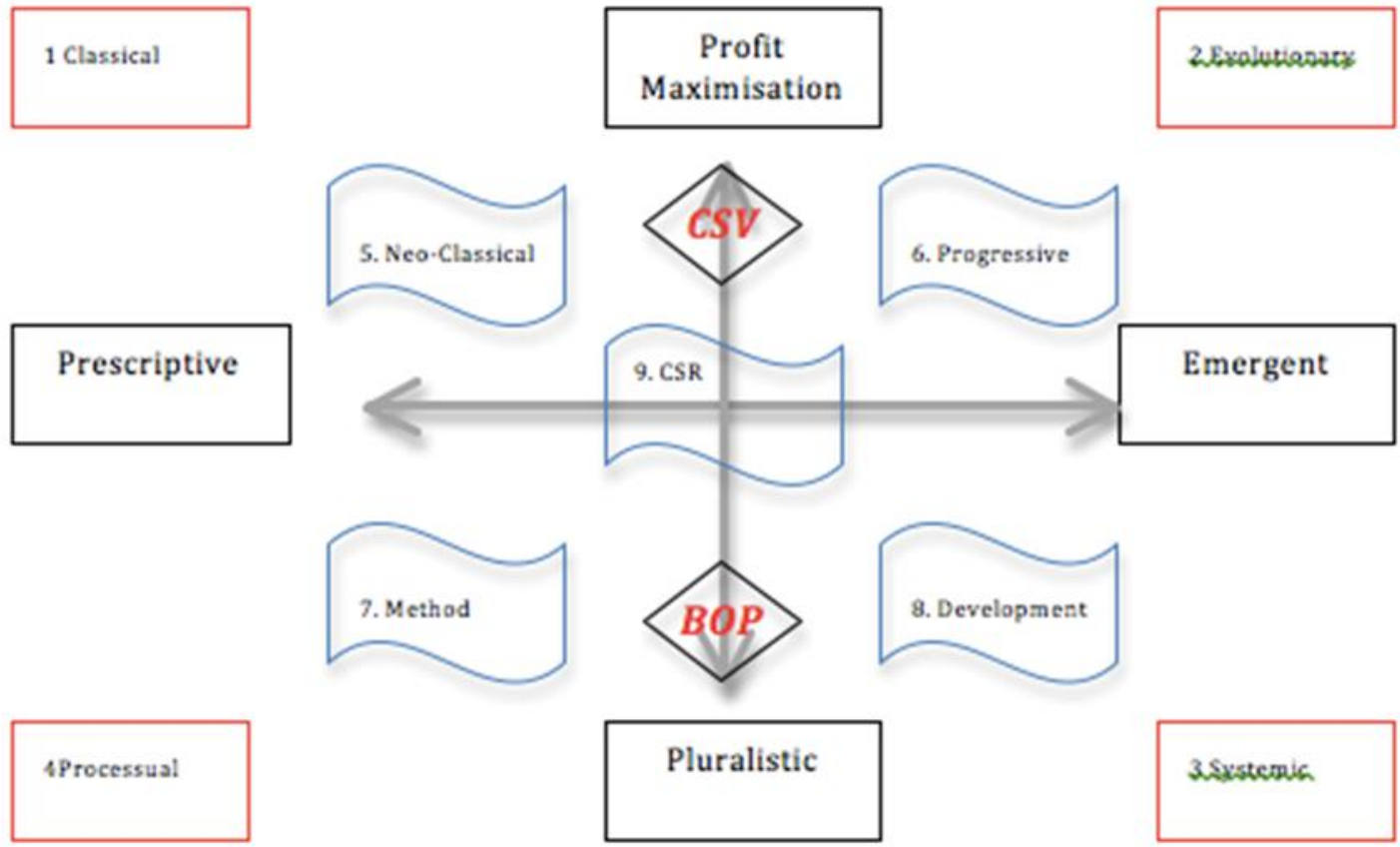

Figure 4: Social Strategy Diagnosis Model 